\title{
LA GENETICA, Y LA EVOLUCION, CONFIRMAN QUE LOS TOROS DE LIDIA SIENTEN DOLOR
}

\author{
Jaume Camps Rabadà \\ Veterinario /. Acad. de Honor en "A.C.Vet.Cat." / Presid. de la "A.Cat. Histo. Vet."
}

\section{GENETICA:}

El Genoma de los bovinos, al que pertenecen los toros de lidia, tienen 29 pares de cromosomas, con dos sexuales, y con 27.000 genes (con idéntico funcionamiento que en los humanos, inclusive en el número completo de cromosomas...) (Y tres mil millones de pares básicos, cifra asimismo coincidente con la de los humanos).

(Datos publicados por la prestigiosa revista "Science" del año 2009)

Existen solo tres subespecies según Taxonomía: La Bos taurus taurus. La Bos taurus indicus (Cebú), y la ancestral origen de todas, la Bos taurus. Alguna clasificación sobre especies domésticas, separadas, no es posible aceptarlas científicamente al ser interfecundas. No existe por tanto una "especie" diferenciada para ser toro de lidia.

(Datos según el "Mammal Species of the World" parte 2079, de la "Comisión Internacional de Normativa Zoológica", del año 2.003)

Dentro del grupo Sentidos, y Etología y Ecología, hay asimismo datos curiosos: Tienen los mismos sentidos que todos los mamíferos. Sentido del tacto muy desarrollado, de forma independiente el aspecto táctil, el del DOLOR, y el térmico,. Además los bovinos son más sensibles a descargas y campo eléctrico, más 
que nosotros. Expresan con bramido y mugido su nivel de hambre, sed, DOLOR, llamadas familiares o de clan. Es gregario hasta formar manadas, como en todas ellas, hay escala social, siendo los alfa los mayores y de mayor cornamenta. Solo con selección exprofesa, y entrenamiento, se consiguen ejemplares más agresivos, aunque no se ha comprobado tenga relación con el DOLOR.

\section{EVOLUCION:}

Desde las Primeras Células eucariontes, de hace más de dos mil millones de años $(2.000,000.000)$, tuvieron que sentir DOLOR, y es mi opinión también que debió ser antes. "Sin ningún tipo de DOLOR no existiria la vida !!!" (frase que reivindico...), ya desde los primeros seres vivos de hace dos mil setecientos millones de años. El LUCA (last universal common ancestror). Hace ya algo más de 600 millones de años con seres multicelulares, y tardaron hasta hace 200 millones de años en aparecer los mamíferos.

El sentir DOLOR, está dentro de toda la evolución. Las primeras células, incluso antes, todas, debieron reaccionar para sobrevivir, aunque lejos de lo que denominamos DOLOR hoy día, pero les molestaba ( molestia que es una forma de DOLOR). PE: un pequeño cambio del $\mathrm{pH}$ del medio donde se iniciaron, o falta de la humedad requerida, o la presencia de oxígeno (que era un tóxico cuando ahora es vida....). Fue un ejercicio gigantesco para superar, y conseguir en estos muchos millones de años la existencia de varios millones de especies animales y vegetales que han existido. No habría ocurrido sin un sentimiento de DOLOR, o molestia !!!.

En toda la evolución se han ido formando tanto la anatomía como la fisiología, que incluye las acciones y reacciones ante el medio externo.

La llegada de la Genética Molecular ha sido básica para la comprensión de la evolución. El ADN es una larga molécula compuesta de una doble cadena, con unidades alternas de azúcar y de fosfato. A cada unidad de azúcar se halla una de 
las cuatro bases del ADN. La cadena puede escindirse en dos, y cada mitad puede sintetizar al complementario. Entre todo este complejo, se determina el mensaje genético de la molécula ADN. Dicho todo muy resumido. Y para iniciar o finalizar el mensaje, hay un triplete que indica un inicio o un final . con el conjunto de mensajes, se consigue un código genético que es universal. (Lo que evidencia el origen común de todos los organismos vivos....)

Cuando existe una modificación de este código, o se pierde si no hay una utilidad para sobrevivir, y superar a otros, o bien significa que de forma caótica, puede servir para hacer sea más adaptable al medio o que se reproduzca mejor, lo que, a lo largo de miles de años consigue que nazca una nueva especie.

Una modificación genética que transformase un ser, en su base fisiológica, en un animal que no llegase a sentir dolor, esta "ventaja", aparente, llevaría a la extinción antes de formarse como nueva especie.

Los toros de raza de lidia son bovinos, y han pasado solo un par de centenas de años con objetivos hacia la tauromaquia, lo que es imposible exista una modificación genética, que requiere millones de años, y en el supuesto muy excepcional de que la falta de DOLOR fuese una ventaja para sobrevivir. (?) El título de la obra de Charles R. Darwin cita que la evolución de las especies, es por selección NATURAL, incluso añade en el original ingles: "On the origin of Species by Means of Nature Selection, or the Preservation of Favoured Races in the Stuggle for Life". Donde ya en el título indica que solo evolucionan las especies que resisten los avatares de la vida....

Evolución que no ha tenido, ni ha podido tener, la raza de toros de lidia. Por tanto sienten DOLOR, como todas las demás especies existentes , y las desaparecidas. JCR. 